\title{
Study of the Long-Term and Dose Dependent Effects of Methylphenidate and Monosodium Glutamate on the Hormonal Alterations of the Pituitary-Testicular Axis and Sperm Analysis in Adolescence Rats
}

\author{
Azad ABDOLLAHZADEH ${ }^{1}$, Davoud KIANIFARD ${ }^{1 *}$, Gholamreza VAFAEI SAIAH ${ }^{2}$ \\ ${ }^{1}$ Division of Histology, Department of Basic Sciences, Faculty of Veterinary Medicine, University of \\ Tabriz, 29 Bahman Boulevard-Postal code: 5166616471, Tabriz, Iran \\ ${ }^{2}$ Division of Physiology, Department of Basic Sciences, Faculty of Veterinary Medicine, University of \\ Tabriz, 29 Bahman Boulevard-Postal code: 5166616471,Tabriz, Iran \\ *corresponding author: davoudkianifard@gmail.com
}

Bulletin UASVM Veterinary Medicine 74(1) / 2017,

Print ISSN 1843-5270; Electronic ISSN 1843-5378

DOI:10.15835/buasvmcn-vm: 12607

\begin{abstract}
Methylphenidate is one of the most common medications that used for maintaining alertness and improving of attention which, may lead to increase of the risk of substance abuse in some cases. Monosodium glutamate is a food additive which has toxic effects on human and animal's tissues. Due to the various side effects of methylphenidate and monosodium glutamate on the reproductive system, the aim of this study was to evaluate the long-term and dose dependent effects of these compounds on the reproductive system during adolescence through hormonal and sperm analysis. Low and high dose of methylphenidate and monosodium glutamate was administrated to adolescent rats for 60 days. Body and testicular weight measurement, pituitary gonadotropins and testosterone levels assays and sperm analysis was performed on euthanized animals. The results showed that, high dose of methylphenidate and low dose of monosodium glutamate and/or combination form of these two compounds have more effects on body and testicular weight alterations. Low dose of methylphenidate with high dose of monosodium glutamate influenced some alterations in follicle stimulating hormone. The distinct use of methylphenidate and monosodium glutamate led to slight elevation in sperm count but simultaneous use of these compounds led to significant elevation of sperm count. The administration of these compounds had negative effect on sperm motility and viability. It has been concluded that, coadministration of methylphenidate and monosodium glutamate through the influence of brain-pituitary-testicular axis and induction of some hormonal alterations may lead to changes in normal function of reproductive system.
\end{abstract}

Keywords: adolescence rats, methylphenidate, monosodium glutamate, pituitary-testicular axis, sperm analysis

\section{INTRODUCTION}

Testicular tissue is one of the most sensitive tissues that could be affected from environmental risk factors. Structural and functional alterations of testicular germ cells can influence the spermatogenesis process (Aitken and Roman, 2008) Methylphenidate (MPH) is one of the most common medications used for treatment of attention-deficit/hyperactivity disorder (Levin and Kleber, 1995; Solanto, 1998; Cansu et al., 2010). The administration of MPH leads to rise in central nervous system activity which could be used for maintaining alertness and improving of attention so, may lead to increase of the risk of substance abuse in some cases (Levin and Kleber, 1995). The occurrence of alteration in female reproductive system such as hormonal secretion changes and altered follicle development has been 
reported (Chatterjee-Chakrabarty et al., 2005). Our previous study showed some alterations in ultrastructure of various cells types in the wall of testicular seminiferous tubules (Mousavi Pourgohar et al., 2016).

Monosodium glutamate (MSG) is the sodium salt of the L-form of glutamic acid. Glutamic acid is one of the most widespread amino acids found in natural products (Samuels, 1999). Despite of MSG's role in improvement of taste stimulation, some studies indicated that MSG has toxic effects on human and animal's tissues (Eweka, 2006). Testicular hemorrhage and alteration of sperm production and morphology are the most reported changes in cases of male infertility after administration of monosodium glutamate (Oforofuo et al., 1997; Eweka, 2006).

According to the various side effects of methylphenidate and monosodium glutamate on the reproductive system and spermatogenesis, the aim of this study was to evaluate the longterm effects of the administration of these substances separately and in combination form on the functional alterations of testicular tissue in adolescence rats.

\section{MATERIAL AND METHODS}

Treatments and chemicals: Monosodium glutamate (Sigma-Aldrich, St Louis, MO 63178, USA) was administrated intraperitoneally in two low (6 mg/kg body weight) and high $(60 \mathrm{mg} /$ kg body weight) doses (Hamzaa et al., 2014). Methylphenidate hydrochloride (Sigma-Aldrich, St Louis, MO 63178, USA) was administrated intraperitoneally in two low $(5 \mathrm{mg} / \mathrm{kg}$ body weight) and high (10 mg/kg body weight) doses (Take et al., 2008).

Animals' procedures and experimental design: 72 adolescent Wistar rats (post-natal day 25) with mean body weight $36.93 \mathrm{~g}$ were divided into nine experimental groups:

1) Control group (Cont.): normal and healthy rats that did not receive any type of treatment;

2) Low dose methylphenidate group (Low MPH);

3) High dose methylphenidate group (High MPH);

4) Low dose monosodium glutamate group (Low MSG);

5) High dose monosodium glutamate group (High MSG);

6) Low dose methylphenidate and monosodium glutamate group (Low MPH+MSG);
7) High dose methylphenidate and monosodium glutamate group (High MPH+MSG);

8) Low dose methylphenidate and high dose monosodium glutamate group (Low MPH+ High MSG);

9) High dose methylphenidate and low dose monosodium glutamate group (High MPH+ Low MSG)

All animals used for testing were housed under a 12 hour light-dark cycle with room temperature of $23-25^{\circ} \mathrm{C}$ and had access to food and water ad libitum. All animal procedures used in this study were approved by the University of Tabriz standards for human care and use of laboratory animals, in accordance with the Ethical Research Committee of the Ministry of Health and Medical Education of Iran (adopted in April 17, 2006) based on the Helsinki Protocol (Helsinki, Finland, 1975). To the animals of control group, similar to other groups, same volume of distilled water was injected intraperitoneally. The duration of experiment was from day 25 after birth until day 85.

Measurement of Body and Testicular Weight: At the beginning of the study, the weight of each animal was recorded and then, the body weight of animals was recorded twice a week during the study. At the end of study, the animals were euthanized and the weight of right and left testes were recorded.

Analytic procedures in plasma samples: At the end of study, the animals were euthanized and blood plasma was separated for hormonal analysis. Testosterone levels were measured by an enzymelinked immunosorbent assay (ELISA) method using a commercial kit (Monobind Inc. USA), blood follicle stimulating hormone (FSH) and luteinizing hormone (LH) levels were determined also by ELISA using specific commercial kits (Pishtazteb diagnostics, Iran).

\section{Sperm analysis}

For analyses of sperm, the cauda epididymis was separated from testis and cut into small pieces into one milliliter of Ham's F10 culture medium. The epididymal sperm count was evaluated by hemocytometer with light microscope at 400x magnification. Sperm motility was assessed with a phase contrast microscope at $400 \times$ magnification. In average 10 microscopic fields were observed and the mean of counted sperms was considered as sperm motility for each rat. To estimate the 
Tab. 1. The mean of body weight and testicular weight in experimental groups.

\begin{tabular}{cccccc}
\hline & $\begin{array}{c}\text { Initial body } \\
\text { weight (g) }\end{array}$ & $\begin{array}{c}\text { Final body } \\
\text { weight }(\mathrm{g})\end{array}$ & $\begin{array}{c}\text { Right testis } \\
\text { weight }(\mathrm{g})\end{array}$ & $\begin{array}{c}\text { Left testis } \\
\text { weight }(\mathrm{g})\end{array}$ & $\begin{array}{c}\text { Total testes } \\
\text { weight }(\mathrm{g})\end{array}$ \\
\hline Cont. & $40.67 \pm 2.309$ & $196.0 \pm 5.657$ & $1.664 \pm 0.061$ & $1.714 \pm 0.081$ & $3.378 \pm 0.140$ \\
\hline Low MPH & $35.50 \pm 1.915$ & $196.0 \pm 21.58$ & $1.491 \pm 0.198^{\beta}$ & $1.552 \pm 0.214^{\beta}$ & $3.043 \pm 0.412^{\beta}$ \\
\hline High MPH & $36.40 \pm 6.229$ & $178.4 \pm 22.24$ & $1.236 \pm 0.182^{*}$ & $1.263 \pm 0.167^{*}$ & $2.501 \pm 0.353^{*}$ \\
\hline Low MSG & $36.00 \pm 2.619$ & $178.8 \pm 17.17$ & $1.312 \pm 0.168^{*}$ & $1.333 \pm 0.165^{*}$ & $2.645 \pm 0.331^{*}$ \\
\hline High MSG & $40.00 \pm 2.828$ & $198.0 \pm 26.16$ & $1.407 \pm 0.213$ & $1.422 \pm 0.186$ & $2.829 \pm 0.398$ \\
\hline Low MPH+MSG & $36.67 \pm 2.066$ & $183.4 \pm 8.848$ & $1.144 \pm 0.070^{*}$ & $1.194 \pm 0.065^{*}$ & $2.339 \pm 0.133^{*}$ \\
\hline High MPH+MSG & $34.33 \pm 1.966$ & $189.3 \pm 8.454$ & $1.530 \pm 0.040 \beta$ & $1.568 \pm 0.054^{\beta}$ & $3.098 \pm 0.086^{\beta}$ \\
\hline Low MPH+ High MSG & $34.40 \pm 2.608$ & $186.4 \pm 10.53$ & $1.313 \pm 0.125$ & $1.374 \pm 0.036$ & $2.687 \pm 0.105^{*}$ \\
\hline High MPH+ Low MSG & $38.40 \pm 3.847$ & $188.8 \pm 16.16$ & $1.502 \pm 0.2499^{\beta}$ & $1.526 \pm 0.246^{\beta}$ & $3.028 \pm 0.494^{\beta}$ \\
\hline $\begin{array}{l}\text { Data are presented as mean } \pm S D .{ }^{*} \text { Significant difference in comparison to control group } ;^{\beta} \text { Significant difference in comparison to Low } \\
\text { MPH+MSG group. }\end{array}$ & & & & &
\end{tabular}

percentage viability, a volume of $20 \mu \mathrm{l}$ of sperm suspension was mixed with an equal volume of $0.05 \%$ eosin-Y. The prepared slides were viewed by a bright-field microscope at $400 \times$ magnification. Two hundred sperms were considered for calculating the indices for the experimental groups (Wyrobek et al., 1983).

Statistical analysis: The obtained results were analyzed using the GraphPad PRISM $®$ software version 5.04 (GraphPad Software, Inc. USA). All data were reported as mean \pm Standard Deviation (SD). The comparison of means between experimental groups was evaluated by using the one way analysis of variance (ANOVA) followed by Tukey's multiple comparison tests. Differences were considered to be statistically significant if $p$ $<0.05$.

\section{RESULTS AND DISCUSSION}

\section{Body weight and testicular weight}

Table 1 summarizes the mean of body weight and testicular weight in the experimental groups. The comparison of initial and final body weight between experimental groups was not showed any significant difference. As Table 1 show, the lowest testes weight was observed in Low MPH+MSG and High MPH groups.

\section{Hormonal assays}

Table 2 shows the blood concentration of pituitary gonadotropins and testosterone in the experimental groups.

According to the results, the administration of higher doses of MPH and MSG was led to slight elevation in blood concentration of FSH and LH. In this regard, a significant increase in blood
FSH levels was observed in Low MPH+ High MSG group. Except for previous mentioned group, the highest level of FSH and LH was observed in High MPH group in comparison to other groups. Moreover, unlike to MPH, high dose of MSG was led to decrease of testosterone level in comparison to low dose of MSG. Between treated groups, the highest blood testosterone levels were observed in Low MPH+MSG group.

\section{Sperm analysis}

The highest sperm count was observed in Low MPH+ High MSG group in comparison to other groups. Accordingly, there was no significant difference between the low and high doses of MPH and MSG. Moreover, unlike to MPH, high dose of MSG was led to decrease of sperm motility and viability indices. The lowest sperm motility and viability indices were observed in Low MPH+MSG group.

Methylphenidate is one of the most common medications used for treatment of attentiondeficit/hyperactivity disorder (Levin and Kleber, 1995; Solanto, 1998; Cansu et al., 2010). This drug can approve for treatment of other disease such as postural orthostatic tachycardia syndrome, narcolepsy, depression and obesity (Doskoch, 2002). The adverse effects of MPH on various body organs are well addressed by previous studies. Restriction in growth, reduction of body weight and the changes in weight of brain, spleen, heart and prostate indicate the effects of this agent on various organs (Jones et al., 1992; Teo et al., 2002; Markowitz et al., 2006).

Despite of MSG's role in improvement of taste stimulation, some studies indicated that MSG 
Tab. 2. Hormonal assay in experimental groups.

\begin{tabular}{cccc}
\hline & FSH (IU/L) & LH (IU/L) & Testosterone (ng/ml) \\
\hline Cont. & $0.28 \pm 0.126^{*}$ & $0.22 \pm 0.043$ & $1.03 \pm 0.687$ \\
\hline Low MPH & $0.30 \pm 0.047^{*}$ & $0.20 \pm 0.028$ & $0.81 \pm 0.613$ \\
\hline High MPH & $0.42 \pm 0.108^{*}$ & $0.26 \pm 0.056$ & $0.94 \pm 0.674$ \\
\hline Low MSG & $0.25 \pm 0.129^{*}$ & $0.20 \pm 0.052$ & $2.00 \pm 1.08$ \\
\hline High MSG & $0.29 \pm 0.078^{*}$ & $0.22 \pm 0.092$ & $0.64 \pm 0.343$ \\
\hline Low MPH+MSG & $0.27 \pm 0.046^{*}$ & $0.20 \pm 0.066$ & $1.18 \pm 0.918$ \\
\hline High MPH+MSG & $0.35 \pm 0.077$ & $0.25 \pm 0.235$ & $0.56 \pm 0.381$ \\
\hline Low MPH+ High MSG & $2.34 \pm 2.321$ & $0.22 \pm 0.139$ & $0.90 \pm 1.02$ \\
\hline High MPH+ Low MSG & $0.30 \pm 0.154^{*}$ & $0.09 \pm 0.066$ & $0.41 \pm 0.254$ \\
\hline Data are presented as mean $\pm S D$. FSH: ${ }^{*}$ Significant difference in comparison to Low MPH+High MSG group.
\end{tabular}

has toxic effects on human and animal's tissues (Eweka, 2006). Some neurotoxic alterations such as brain damage and endocrine disorders have been seen after administration of monosodium glutamate (Miksowiak et al., 1993; Mozes et al., 2004). Male infertility, reduction of body growth, obesity and hypogonadism has been reported following administration of MSG (Pizzi et al., 1979; Onakewhor et al., 1998).

It has been reported that, the administration of MPH in rats could result in disturbances of brain-pituitary-testicular axis (Adriani et al., 2006). The pituitary gonadotropins, i.e. FSH and LH, act synergistically for stimulation of androgen biosynthesis; therefore, the reduction of these gonadotropins play an important role in decrement of testosterone production (Orth et al., 1979). It is believed that, the MPH works through stimulation of dopamine transporter and D2 receptors. Moreover, it is well established that the rat testicular tissue and spermatozoa have D2 and several adrenergic receptors (Kuczenski and Segal, 1997; Adeoya-Osiguwa et al., 2006; Otth et al., 2007).

Glutamate receptors have been identified in several tissues and organs including the hypothalamus, spleen, thymus, liver, kidney, endocrine glands and the ovaries. In this regard, some studies demonstrated glutamate receptors in testicular tissue of rats (Gill et al., 2000; Takarada et al., 2004).

Our results showed that, the highest weight gain was seen in low MPH and High MSG groups. In other groups which treated with high dose of MSG along with Low or high MPH the mean of weight gain was more in comparison to other groups.
Moreover, the lowest weight gain was observed in High MPH group. There are different reports regarding the effects of MPH on body weight. Several studies on animal models reported the relationship between administration of MPH and body weight loss (Gulati et al., 1997; Fazelipour et al., 2012), whereas other studies reported some different results (Cansu et al., 2010). The administration of monosodium glutamate leads to increase of body weight (Diniz et al., 2005). According to our previous study, the higher dose of MSG led to more weight gain in comparison to lower doses of monosodium glutamate (Kianifard et al., 2015). The results of the present study are in consistent with previously reported results.

According to our results, the weight of testes was reduced significantly in four groups (High $\mathrm{MPH}$; Low MSG; Low MPH+MSG and Low MPH+ High MSG) in comparison to control rats. It seems that, the changes of mean testicular weight are in accordance to changes of body weight. The administration of monosodium glutamate is associated with reduction of testicular weight (Olney et al., 1972). Also, in some studies the testicular weight reduction was reported after administration of cocaine hydrochloride $(15 \mathrm{mg} /$ $\mathrm{kg}$ ), which is structurally similar to MPH (George et al., 1996). The weight of testes depends on the mass of differentiated spermatogenic cells (Katoh et al., 2002). The results from this study confirms our previous studies (Kianifard et al., 2013; Kianifard et al., 2015) about the effects of methylphenidate and monosodium glutamate on testicular weight loss especially when these agents both taken together. 
Tab. 3. Epididymal sperm analysis in experimental groups.

\begin{tabular}{|c|c|c|c|}
\hline & $\begin{array}{c}\text { Sperm count } \\
(\# \text { cell } \times 150000 / \mathrm{ml})\end{array}$ & Sperm motility (\%) & Sperm viability (\%) \\
\hline Cont. & $15.80 \pm 6.101$ & $62.72 \pm 13.91$ & $74.85 \pm 14.47$ \\
\hline Low MPH & $17.20 \pm 4.671^{\beta}$ & $43.42 \pm 19.07^{*}$ & $53.62 \pm 9.674^{*}$ \\
\hline High MPH & $17.88 \pm 5.502^{\beta}$ & $49.33 \pm 16.13^{\beta}$ & $62.23 \pm 11.66$ \\
\hline Low MSG & $16.94 \pm 3.110^{\beta}$ & $50.81 \pm 12.43^{\beta}$ & $62.15 \pm 12.74$ \\
\hline High MSG & $16.26 \pm 3.906^{\beta \pi}$ & $47.64 \pm 22.12^{\beta}$ & $59.31 \pm 12.44^{*}$ \\
\hline Low MPH+MSG & $20.00 \pm 3.413^{\beta}$ & $31.01 \pm 15.24^{*}$ & $49.69 \pm 8.350^{*}$ \\
\hline High MPH+MSG & $15.67 \pm 3.315^{\beta \pi}$ & $52.56 \pm 16.24^{\beta}$ & $67.00 \pm 14.57^{\beta}$ \\
\hline Low MPH+ High MSG & $27.68 \pm 8.469^{*}$ & $51.65 \pm 17.01^{\beta}$ & $60.46 \pm 11.93$ \\
\hline High MPH+ Low MSG & $21.32 \pm 5.281^{* \beta}$ & $46.44 \pm 17.63^{\beta}$ & $62.38 \pm 14.26$ \\
\hline
\end{tabular}

Previous studies have shown that, the MPH can alter the brain-pituitary-testicular axis (Adriani et al., 2006). The results of our study showed that, higher doses of MPH and MSG led to slight elevation in blood levels of FSH and LH. Accordingly, excepting for FSH the mean of LH and Testosterone levels were not changed significantly between experimental groups. The elevation of LH levels following the administration of higher doses of MPH and MSG could be due to reduction of its target cells population. In this connection, according to previous studies, the alterations in number of Leydig cells are happening following the administration of MPH and other similar agents (Tsai et al., 1996; Taghva et al., 2007; Fazelipour et al., 2012). It has been reported that, the administration of monosodium glutamate is associated with the reduction of $\mathrm{LH}$ and testosterone levels (Sakr and Badawy, 2013). The results obtained from our study showed that, lower doses of MSG could be effective in elevation of testosterone levels whereas, higher doses of MSG lead to decrement of testosterone levels. Hypothalamic neuronal cell death is specified following the administration of MSG to adult mice (Park et al., 2000). Moreover, neuronal cell death of hypothalamic arcuate and preoptic nucleuses has been documented in some studies (Olney, 1969; Garattini, 2000). As a result, hypothalamicpituitary-gonadal axis dysfunction can lead to testicular functional alterations (Nayanatara et al., 2008).

In this study, the epididymal sperm population was increased following the administration of
MPH and MSG in comparison to control group. It seems that, this increment in sperm population observes in more degrees in MPH+MSG groups. Some studies addressed that, the sperm quantity increased by lower doses of MPH (25) which is in accordance with our results. The results of our study showed that, administration of MSG leads to slight elevation of sperm population compared to control group. In this regard, some previous studies reported the reduction of epididymal sperm population following administration of monosodium glutamate (Onakewhor et al., 1998; Giovambattista et al., 2003; Nayanatara et al., 2008). According to our results, the lowest sperm motility and viability rate was seen in Low MPH and Low MPH+MSG groups. This result could reflect this fact that the use of methylphenidate and monosodium glutamate can influence the sperm structure and function.

\section{CONCLUSIONS}

It has been concluded that, coadministration of methylphenidate and monosodium glutamate through the influence of brain-pituitary-testicular axis and induction of some hormonal alterations may lead to changes in normal function of reproductive system.

Acknowledgments: This work was financially supported by research council of University of Tabriz.

Conflict of interest: The authors declare that they have no conflict of interest. 


\section{REFERENCES}

1. Adeoya-Osiguwa SA, Gibbons R, Fraser LR (2006). Identification of functional alpha2- and betaadrenergic receptors in mammalian spermatozoa. Hum Reprod 21:1555-1563.

2. Adriani W, Leo D, Guarino M, Natoli A, Di Consiglio E, De Angelis G, Traina E, Testai E, Perrone-Capano C, Laviola G (2006). Short-term effects of adolescent methylphenidate exposure on brain striatal gene expression and sexual/ endocrine parameters in male rats. Ann NY Acad Sci 1074:52-73.

3. Aitken RJ, Roman SD (2008). Antioxidant systems and oxidative stress in the testes. Oxid Med Cell Longev 1:1524.

4. Cansu A, Ekinci O, Ekinci O, Serdaroglu A, Erdogan D, Coskun ZK, Gurgen SG (2010). Methylphenidate has dose-dependent negative effects on rat spermatogenesis: decreased round spermatids and testicular weight and increased p53 expression and apoptosis. Hum Exp Toxicol 30:1592-600.

5. Chatterjee-Chakrabarty S, Miller BT, Collins TJ, Nagamani $M$ (2005). Adverse effects of methylphenidate on the reproductive axis of adolescent female rats. Fertil Steril 84(Suppl 2):1131-1138.

6. Diniz Y, Faine LA, Galhardi CM, Rodrigues HG, Ebaid GX, Burneiko RC, Cicogna AC, Novelli EL (2005). Monosodium glutamate in standard and high-fiber diets: metabolic syndrome and oxidative stress in rats. Nutrition 21: 749755

7. Doskoch $P$ (2002). Why isn't methylphenidate more addictive? NeuroPsychiatry Rev 3:19.

8. Eweka A (2006). Histological studies of the effects of monosodium glutamate on the kidney of adult Wistar rats. Internet J Health 6: 2.

9. Fazelipour S, Hadipour Jahromy M, Tootian Z, Kiaei SB, Sheibani MT, Talaee N (2012). The effect of chronic administration of methylphenidate on morphometric parameters of testes and fertility in male mice. J Reprod Infertil 13:232-236.

10. Garattini S (2000). Glutamic acid, twenty years later. J Nutr 130 [4S Suppl]: 901S-909S.

11. George VK, Li H, Teloken C, Grignon DJ, Lawrence WD, Dhabuwala CB (1996). Effects of long-term cocaine exposure on spermatogenesis and fertility in peripubertal male rats. J Urol 155:327-331.

12. Giovambattista A, Suescun MO, Nessralla CC, Franca LR, Spinedi E, Calandra RS (2003). Modulatory effects of leptin on Leydig cell function of normal and hyperleptinemic rats. Neuroendocrinology 78: 270-279.

13. Gill SS, Mueller RW, McGuire PF, Pulido OM (2000). Potential target sites in peripheral tissues for excitatory neurotransmission and excitotoxicity. Toxicol Pathol 28: 277-284.

14. Gulati D, Hope E, Mounce R, Russell S (1997). Methylphenidate Hydrochloride. Environ Health Perspect 105:319-320.

15. Hamzaa RZ, AL-Harbi MS (2014). Monosodium glutamate induced testicular toxicity and the possible ameliorative role of vitamin E or selenium in male rats. Toxicol Reports 1: 1037-1045.

16. Jones JR, Caul WF, Hill JO (1992). The effects of amphetamine on body weight and energy expenditure. Physiol Behav 51:607-611.

17. Katoh C, Kitajima S, Saga Y, Kanno J, Horii I, Inoue T (2002). Assessment of quantitative dual-parameter flow cytometric analysis for the evaluation of testicular toxicity using cyclophosphamide and ethinylestradiol treated rats. J Toxicol Sci 27:87-96.

18. Kianifard D, Hasanzadeh S, Kianifard L (2013). The study of Time Dependent Administration of Methylphenidate on the Microscopic Indices of Spermatogenesis and Sperm Analysis in Adult Rats. J Exp Integ Med 3(2):121-125.

19. Kianifard D, Vafaei Saiah Gh, Rezaee F (2015). Study of the Protective Effects of Quince (Cydonia Oblonga) Leaf Extract on Fertility Alterations and Gonadal Dysfunction Induced By Monosodium Glutamate in Adult Male Wistar Rats. Rom J Diabetes Nutr Metab Dis 22(4): 375-384.

20. Kuczenski R, Segal DS (1997). Effects of methylphenidate on extracellular dopamine, serotonin, and norepinephrine: comparison with amphetamine. J Neurochem 68:20322037.

21. Levin FR, Kleber HD (1995). Attention-deficit hyperactivity disorder and substance abuse: relationships and implications for treatment. Harv Rev Psychiatry 2:246-58.

22. Markowitz JS, DeVane CL, Pestreich LK, Patrick KS, Muniz $R$ (2006). A comprehensive in vitro screening of $d-,-l$, and dl-threo-methylphenidate: an exploratory study. J Child Adolesc Psychopharmacol 16:687-698.

23. Miksowiak B, Partyka M (1993). Effects of neonatal treatment with MSG (monosodium glutamate) on hypothalamo-pituitary-thyroid axis in adult male rats. Histol Histopathol 8: 731-734.

24. Mousavi Pourgohar Z, Kianifard D, Khalilzadeh E (2016). The Microscopic and Ultra Structural Study of Testicular Tissue Following Time Dependent Administration of Methylphenidate in Adult Rats. SJIMU 24(4): 83-94.

25. Mozes S, Sefcíková Z, Lenhardt L, Racek L (2004). Obesity and changes of alkaline phosphatase activity in the small intestine of 40- and 80-day old rats subjected to early postnatal overfeeding of monosodium glutamate. Physiol Res 53: 177-186.

26. Nayanatara AK, Vinodini NA, Damodar G, Ahemed B, Ramaswamy CR, Shabarianth,Ramesh Bhat M (2008). Role of ascorbic acid in monosodium glutamate mediated effect on testicular weight, sperm morphology and sperm count, in rat testis. J Chin Clin Med 3: 1-5.

27. Oforofuo IAO, Onakewhor JUE, Idaewor PE (1997). The effect of chronic administration of MSG on the histology of the adult Wistar rat testis. Bioscience Res Comm 9: 1-2.

28. Olney JW (1969). Brain lesions, obesity, and other disturbances in mice treated with monosodium glutamate. Science 164(3880): 719-721.

29. Olney JW, Sharpe LG, Feigin RD (1972). Glutamateinduced brain damage in infant primates. J Neuropathol Exp Neurol 31: 464-488. 
30. Onakewhor JUE, Oforofuo IAO, Singh SP (1998). Chronic administration of monosodium glutamate induces oligozoospermia and glucogen accumulation in Wistar rat testes. African J Reprod Health 2: 190-197.

31. Orth JM, Murray FT, Bardin CW (1979). Ultrastructural changes in Leydig cells of streptozotocin-induced diabetic rats. Anat Rec 195:415-430.

32. Otth C, Torres M, Ramirez A, Fernandez JC, Castro M, Rauch MC, Brito M, Yanez AJ, Rodriguez-Gil JE, Slebe JC, Concha II (2007). Novel identification of peripheral dopaminergic D2 receptor in male germ cells. J Cell Biochem 100:141150.

33. Park CH, Choi SH, Piao Y, Kim S, Lee YJ, Kim HS, Jeong SJ, Rah JC, Seo JH, Lee JH, Chang K, Jung YJ, Suh YH (2000). Glutamate and aspartate impair memory retention and damage hypothalamic neurons in adult mice. Toxicol Lett 115: 117-125.

34. Pizzi WJ, Barnhart JE, Unnerstall JR (1979). Reproductive dysfunction in male rats following neonatal administration of monosodium L-glutamate. Neurobehav Toxicol 1: 1-4.

35. Sakr SA, Badawy GM (2013). Protective effect of curcumin on monosodium glutamate-induced reproductive toxicity in male albino rats. Glob J Pharmacol 7: 416-422.

36. Samuels A (1999). The toxicity/safety of processed free glutamic acid (MSG): a study in suppression of information. Account Res 6: 259-310.

37. Solanto MV (1998). Neuropsychopharmacological mechanisms of stimulant drug action in attention-deficit hyperactivity disorder: a review and integration. Behav Brain Res 94:127-52.

38. Taghva M, Toutian Z, Fazelipour S (2007). Effects of formaldehyde on morphometric structure of testis in Balb/C mice. Med Sci J Islam Azad Univ 17:91-3.

39. Takarada TE, Hinoi E, Balcar VJ, Taniura H, Yoneda Y (2004). Possible expression of functional glutarnate transporters in the rat testis. J Endocrinol 181: 233-244.

40. Take G, Bahcelioglu M, Oktem H, Tunc E, Gözil R, Erdogan D, Calguner E, Helvacioglu F, Giray SG, Elmas C (2008). Dosedependent immunohistochemical and ultrastructural changes after oral methylphenidate administration in rat heart tissue. Anat Histol Embryol 37(4):303-308.

41. Teo S, Stirling D, Thomas S, Hoberman A, Kiorpes A, Khetani V (2002). A 90-day oral gavage toxicity study of D-methylphenidate and D,L-methylphenidate in SpragueDawley rats. Toxicology 179:183-196.

42. Tsai SC, Chiao YC, Lu CC, Doong ML, Chen YH, Shih HC, Liaw C, Wang SW, Wang PS (1996). Inhibition by amphetamine of testosterone secretion through a mechanism involving an increase of cyclic AMP production in rat testes. Br J Pharmacol 118:984-988.

43. Wyrobek AJ, Gordon LA, Burkhart JG, Francis MW, Kapp RW Jr, Letz G, Malling HV, Topham JC, Whorton MD (1983). An evaluation of the mouse sperm morphology test and other sperm tests in nonhuman mammals. A report of the US Environmental Protection Agency Gene-Tox Program. Mutat Res 115: 1-72. 